\title{
Influence of filtering and biodeposition by the cultured scallop Chlamys farreri on benthic- pelagic coupling in a eutrophic bay in China
}

\author{
Yi Zhou*, Hongsheng Yang**, Tao Zhang, Shilin Liu, Shumei Zhang, Qun Liu, \\ Jianhai Xiang, Fusui Zhang
}

Key Laboratory of Marine Ecology and Environmental Sciences, Institute of Oceanology, Chinese Academy of Sciences, Qingdao 266071, PR China

\begin{abstract}
In coastal ecosystems, suspension-cultured bivalve filter feeders may exert a strong impact on phytoplankton and other suspended particulate matter and induce strong pelagic-benthic coupling via intense filtering and biodeposition. We designed an in situ method to determine spatial variations in the filtering-biodeposition process by intensively suspension-cultured scallops Chlamys farreri in summer in a eutrophic bay (Sishili Bay, China), using cylindrical biodeposition traps directly suspended from longlines under ambient environmental conditions. Results showed that bivalve filtering-biodeposition could substantially enhance the deposition of total suspended material and the flux of $\mathrm{C}, \mathrm{N}$ and $\mathrm{P}$ to the benthos, indicating that the suspended filter feeders could strongly enhance pelagic-benthic coupling and exert basin-scale impacts in the Sishili Bay ecosystem. The biodeposition rates of 1-yr-old scallops varied markedly among culture sites (33.8 to $133.0 \mathrm{mg}$ dry material ind. ${ }^{-1} \mathrm{~d}^{-1}$ ), and were positively correlated with seston concentrations. Mean $\mathrm{C}, \mathrm{N}$ and P biodeposition rates were $4.00,0.51,0.11 \mathrm{mg}$ ind.$^{-1} \mathrm{~d}^{-1}$, respectively. The biodeposition rates of 2-yr-old scallops were almost double these values. Sedimentation rates at scallop culture sites averaged 2.46 times that at the reference site. Theoretically, the total water column of the bay could be filtered by the cultured scallops in $12 \mathrm{~d}$, with daily seston removal amounting to $64 \%$. This study indicated that filteringbiodeposition by suspension-cultured scallops could exert long-lasting top-down control on phytoplankton biomass and other suspended material in the Sishili Bay ecosystem. In coastal waters subject to anthropogenic $\mathrm{N}$ and $\mathrm{P}$ inputs, suspended bivalve aquaculture could be advantageous, not only economically, but also ecologically, by functioning as a biofilter and potentially mitigating eutrophication pressures. Compared with distribution-restricted wild bivalves, suspension-cultured bivalves in deeper coastal bays may be more efficient in processing seston on a basin scale.
\end{abstract}

KEY WORDS: Biodeposition · Filtering $\cdot$ Bivalve $\cdot$ Chlamys farreri $\cdot$ Suspension aquaculture $\cdot$ Longline $\cdot$ Top-down control $\cdot$ Benthic-pelagic coupling $\cdot$ Eutrophication

\section{INTRODUCTION}

In shallow coastal and estuarine waters, benthic filter feeders (e.g. bivalves) often dominate the benthos in numbers as well as in biomass. Previous studies have demonstrated that dense assemblages of filterfeeding bivalve molluscs in shallow waters can play a significant role in coupling pelagic and benthic organic matter flow, as well as controlling material recycling (Jordan \& Valiela 1982, Kautsky \& Evans 1987, Loo \& Rosenberg 1989, Dame et al. 1991, Chian- tore et al. 1998, Norkko et al. 2001, Newell 2004, Zhou et al. 2006a). Filter-feeding bivalves are well known for their great filtering capacity. They are important phytoplankton consumers in coastal waters and thus dense assemblages could remove a large amount of phytoplankton and other suspended particulate matter from the water column as a natural cleansing process, including sediment and organic detritus, bacteria, invertebrate larvae, and many kinds of nano-, microand mesozooplankton (Wong et al. 2003). The high consumption of suspended particulate matter by filter- 
feeding bivalves is partly routed to metabolism, growth and production of offspring. A large part of the filtered organic and inorganic particulate materials, however, is packaged into faeces and pseudofaeces (biodeposits) that finally settle to the bottom, and this is referred to here as the filtering-biodeposition process. Since faeces and pseudofaeces are voided from the animal body as mucus-bound aggregates, they are larger and more prone to sedimentation than the nonaggregated particles from which they are formed, and deposit at rates up to 40 times that of nonaggregated particles (Kautsky \& Evans 1987, Widdows et al. 1998, Giles \& Pilditch 2004). Consequently, the filtering-biodeposition process can be extremely important in regulating water column processes and pelagicbenthic coupling when bivalves are abundant in coastal waters (Prins et al. 1998, Newell 2004). A high production of biodeposits can result in an enrichment of sediment with organic matter, providing a major source of food to benthic meio- and macrofauna and serving as a food resource for secondary consumers (Lopez \& Levinton 1987, Zhou et al. 2006b). Also, the enrichment of nitrogen and phosphorus in the sediment may promote the growth of micro- and macrophytobenthos (Peterson \& Heck 1999, Newell 2004). Therefore, dense filter-feeding bivalve populations can act as a conduit for nutrients to the benthos (Peterson \& Heck 1999), and the increased organic deposition can then enhance nutrient regeneration, and thereby refuel pelagic activity (Asmus \& Asmus 1991). In fact, it is argued that dense assemblages of filterfeeding bivalves are more important as agents of sedimentation and nutrient cycling than as components of energy flow (Kautsky \& Evans 1987, Dame et al. 1991).

Bivalve filter feeders are essential to the ecological system as well as to the economic potential of the waters. Through consumption and deposition of suspended particulate matter, natural bivalve populations are known to reduce total suspended particulate matter in the water column and exert a top-down control on phytoplankton biomass (Cloern 1982, Officer et al. 1982, Haamer 1996, Cerrato et al. 2004, Zhou et al. 2006a). Filter-feeding bivalves often act as keystone species in healthy coastal ecosystems (Dame 1996). Filtering-biodeposition by dense bivalve populations can reduce water column turbidity, and enhance light penetration in the water to the advantage of lightdependent benthic plants (Newell 2004). Since preindustrial times, urban and coastal development has widely accelerated the fluxes of the nutrients nitrogen and phosphorus to coastal waters and caused eutrophication. Phytoplankton biomass is determined by bottom-up (i.e. nutrients, light) and top-down (i.e. filtering) forces; but in bivalve-abundant systems, top-down control will prevail in most cases, so that increasing nutrient loading may result in only a limited response in phytoplankton biomass (Prins et al. 1998). Consequently, filter-feeding bivalves can improve water quality in eutrophic waters by exerting top-down control on phytoplankton stocks (Newell 2004, and references therein), and may potentially mitigate eutrophication pressures on coastal ecosystems through aquaculture (Gottlieb \& Schweighofer 1996, Haamer 1996, McCay et al. 2003, Gifford et al. 2004, Zhou et al. 2006a).

Compared with wild bivalves, much less work has been conducted on cultivated bivalves. Cultivated bivalves may also play a key role in coastal ecosystems due to their high filtration capacity and culture density (Newell 2004). Heavy biodeposition under mussel and oyster rafts has been reported (Dahlbäck \& Gunnarsson 1981, Tenore et al. 1982). The culture of bivalve shellfish is potentially one of the most sustainable forms of mariculture; it is widely distributed and requires no artificial food input, since the animals obtain all their nutrition from phytoplankton and other organic detritus (e.g. Grant 1999, Nunes et al. 2003). Nevertheless, the rapid growth of the industry has inevitably raised questions of carrying capacity and sustainability (e.g. Grant 1999). As more living biomass is accumulated, the proportion of primary production available for further growth of bivalve biomass decreases (Dame \& Prins 1998), and the biodeposition by dense bivalve populations may be so intense that the stimulated microbial respiration can result in anoxia in underlying sediments (Dahlbäck \& Gunnarsson 1981, Stenton-Dozey et al. 2001). In recent years, there have been an increasing number of studies on the impacts of cultured bivalves on coastal ecosystems, as the aquaculture industry grows (Kaiser et al. 1998, Newell 2004).

Suspension aquaculture of bivalve filter feeders, such as scallops, mussels and oysters, has been developing rapidly and widely in coastal waters throughout the world. Suspended scallop aquaculture is practised in Asia (e.g. China, Japan), Europe (e.g. France, United Kingdom), North America (e.g. Canada), South America (e.g. Peru) and Oceania (e.g. New Zealand, Australia). With the culture scale enlarging, it is likely that the filtering-biodeposition process by cultured bivalves will have functional effects on coastal ecosystems, especially those subject to anthropogenic nutrient loading.

Bivalve mariculture in the coastal waters of China has been growing especially rapidly in the past 2 decades; it is by far the largest and best-known in the world, with a culture area of ca. $0.8 \times 10^{6} \mathrm{ha}$, and an annual production of ca. $9.6 \times 10^{6} \mathrm{t}$, accounting for more than $70 \%$ of the world production (Guo et al. 1999, Zhang 2003, FAO 2004). Suspension aquaculture from 
longlines is an extremely important cultivation method for bivalves (oyster, mussel and scallop) in China and, in large-scale bivalve culture, may dominate an entire bay, such as in Sungo Bay (Grant \& Bacher 2001) and Sishili Bay (Yang et al. 1999) where this study was conducted. Scallops are among the main bivalve species cultured in China, reaching an annual production of about $10^{6} \mathrm{t}$ in 1997 (Guo et al. 1999). The Zhikong scallop Chlamys farreri (Jones et Preston) is an epifaunal and subtidal filter feeder, and naturally inhabits temperate hard-substrate coasts of northern China, Korea, Japan and eastern parts of Russia. It is a major culture species in coastal waters of northern China where it reaches high values in biomass and density and may exert a heavy impact on the water column (seston level) and benthic environment (bottom physical and chemical conditions). In recent years, intensive culture of this species has led to negative effects such as retarded growth and increased mortality. Mass mortality has occurred in many farming areas in China, including Sishili Bay; during the summer and early autumn, the mortality reached over $60 \%$. Harmful algae blooms (HAB) damaged scallop culture areas of Sishili Bay in early September 1998. Although the exact cause for the mortality and the HAB remains unknown, overcrowding of the cultured scallops was commonly considered to be responsible (Guo et al. 1999, Zhang \& Yang 1999).

In order to understand and solve the mortality problem, the impact of intensively cultured scallops on the environment and the carrying capacity for scallop culture should be estimated. The carrying capacity in connection with shellfish aquaculture is defined as the maximum stocking density achievable without causing food depletion or population mortalities (Smaal, et al. 1998). In recent years, demands have increased for predicting the carrying capacity for culture of filterfeeding bivalves within nearshore environments, and for understanding the impact of the bivalves on ecosystem dynamics (Dame \& Prins 1998). In order to model the carrying capacity, it is necessary to evaluate the role of filter-feeding bivalve molluscs in coastal ecosystem dynamics, which requires accurate quantification of the filtering-biodeposition process (Cranford \& Hargrave 1994, Prins et al. 1998, Grant unpubl.1.). Filtering and biodeposition rates are probably the best parameters for quantifying the impact of filter-feeding bivalves on material cycling (Chiantore et al. 1998).

Previous studies on the filtering-biodeposition process by bivalve molluscs have been conducted in situ

\footnotetext{
${ }^{1}$ Grant J (2001) Seston variation and its effects on modelling environmental impact of shellfish culture. Available at: www. aquacultureassociation.ca/ac2001/ShellfishNutrition.htm
}

on the seabed using sediment traps (e.g. Kautsky \& Evans 1987, Jaramillo et al. 1992, Klerks et al. 1996, Peterson \& Heck 1999). Although suspended bivalve aquaculture has been practised worldwide, little work has focussed on the in situ filtering-biodeposition process by the cultured bivalves. It has been recognized that differences in food availability act on bivalve physiological processes on various spatial scales, ranging from whole basins to individual culture units (e.g. Navarro et al. 1991, Labarta 1997). Surprisingly, few studies on basin-scale spatial variation in filteringbiodeposition process have been conducted in coastal ecosystems. In Sishili Bay, differences in food availability among culture sites are likely to occur (Yang et al. 1999, Zhou 2000); such variability may have effects on scallop filtering-biodeposition, and growth. In this study we measured the filtering-biodeposition process of the suspension-cultured scallops, using an in situ method, and investigated its spatial variations in a eutrophic bay, and thereby the effects on the pelagic and benthic environment.

\section{MATERIALS AND METHODS}

Study area. Sishili Bay, located in the northeast of Shandong Province (the largest producer of cultured bivalves in China), is a $130 \mathrm{~km}^{2}$ embayment on the Yellow Sea coast in northern China (Fig. 1). Along the coastline of the bay is Yantai City, a rapidly developing area. The bay is one of the most intensive culture areas in China, or indeed in the world. Suspension aquaculture activity in the bay has been practised for over 2 decades, with an estimated standing stock of $30000 \mathrm{t}$ of

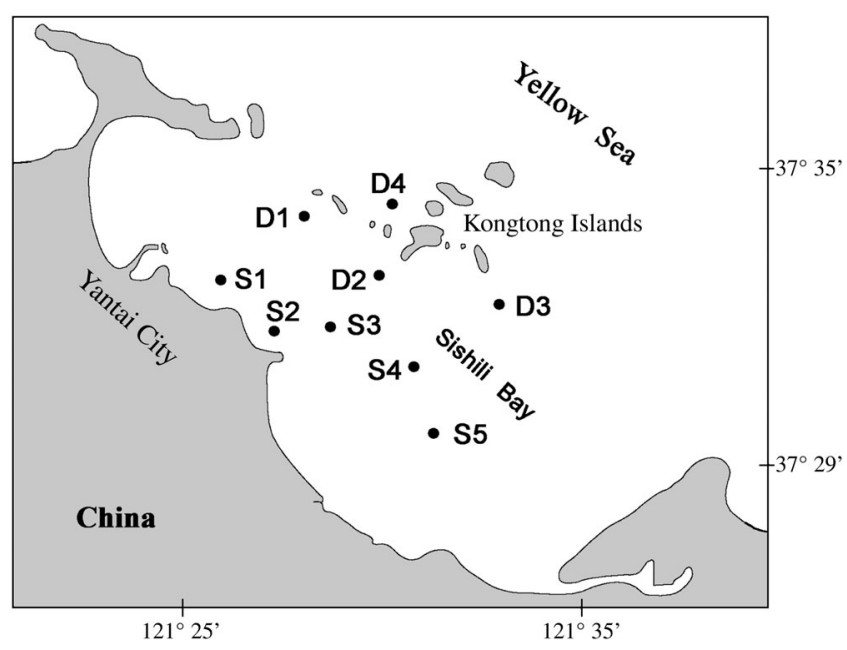

Fig. 1. Sishili Bay and experimental sites for this study. Stn S4 was a reference site where no scallops were cultured; the remaining stations are scallop culture sites 
scallops. The Zhikong scallop Chlamys farreri is the main cultured bivalve species. In Sishili Bay, average water depth is 8 to $9 \mathrm{~m}$ (max. $20 \mathrm{~m}$ ), with a tidal range of $1.66 \mathrm{~m}$. Along the bay there are $78 \mathrm{~km}^{2}$ of cropland and $2 \mathrm{~km}^{2}$ of mountain and forest. There are several small rivers flowing into the bay; the longest one is Xinan River with a length of $48.5 \mathrm{~km}$ and a maximum floodwater flux of $1160 \mathrm{~m}^{3} \mathrm{~s}^{-1}$. Substantial eutrophication occurred in the bay in 1998 as a consequence of anthropogenic inputs, including nutrient enrichment due to activities such as urban industrial and domestic effluent discharge and agricultural fertilizer runoff from growing human populations and urban development in coastal areas (e.g. Wu et al. 2001). Scallop culture is carried out in almost the entire bay, accounting for ca. $70 \%$ of the bay area. Scallops are mainly cultured at a depth of 1.5 to $3 \mathrm{~m}$ below the surface in lantern nets suspended from longlines. A lantern net is generally divided into 10 cells by plastic perforated plates (30 cm diameter). C. farreri is cultured at a density of 300 to 400 individuals per lantern net. Growout of the cultured scallop is achieved in 1.5 to $2 \mathrm{yr}$. More information on the physical and biological conditions of Sishili Bay is available elsewhere (Yang et al. 1999). The bay has been extensively studied to evaluate the ecosystem processes and carrying capacity for scallop culture in the bay.

Biodeposition and natural sedimentation. Experiments to estimate the filtering-biodeposition process by Chlamys farreri were conducted in summer (June-July) 1999. Eight stations, located inside different scallop farming sites, were chosen to represent the various shellfish farming environments of the whole bay. Of these, 4 stations, labeled $\mathrm{S}$, were arrayed along the coastline (5 to $12 \mathrm{~m}$ in depth), and 4 stations, labeled $\mathrm{D}$, along the islands (9-14 $\mathrm{m}$ in depth). One additional station (9 $\mathrm{m}$ in depth; $\mathrm{S} 4)$, where no culture activities were practised and which was located ca. $100 \mathrm{~m}$ from the nearest scallop farming zone, was chosen as the reference site. It was very difficult to find more non-culture sites to be used as reference sites because of the large scale of bivalve aquaculture in the bay. During this experimental period, the primary production $(509 \mathrm{mg} \mathrm{C}$ $\mathrm{m}^{-2} \mathrm{~d}^{-1}$ ) was at the highest of the year (Wu \& Zhang 2001). Rates of natural sedimentation and biodeposition by the scallops were examined using PVC cylindrical biodeposit traps (30 cm I.D., $80 \mathrm{~cm}$ in length; Fig. 2), to which no preservatives were added, following other studies on bivalve biodeposition (Kautsky \& Evans 1987, Jaramillo et al. 1992, Hatcher et al. 1994, Klerks et al. 1996, Peterson \& Heck 1999, Norkko et al. 2001). For accurate determination of biodeposition by lantern-netcultured scallops we modified the traditional biodeposit-trap design, in that the inner diameter of the cylinders was enlarged to the same as that of the plastic

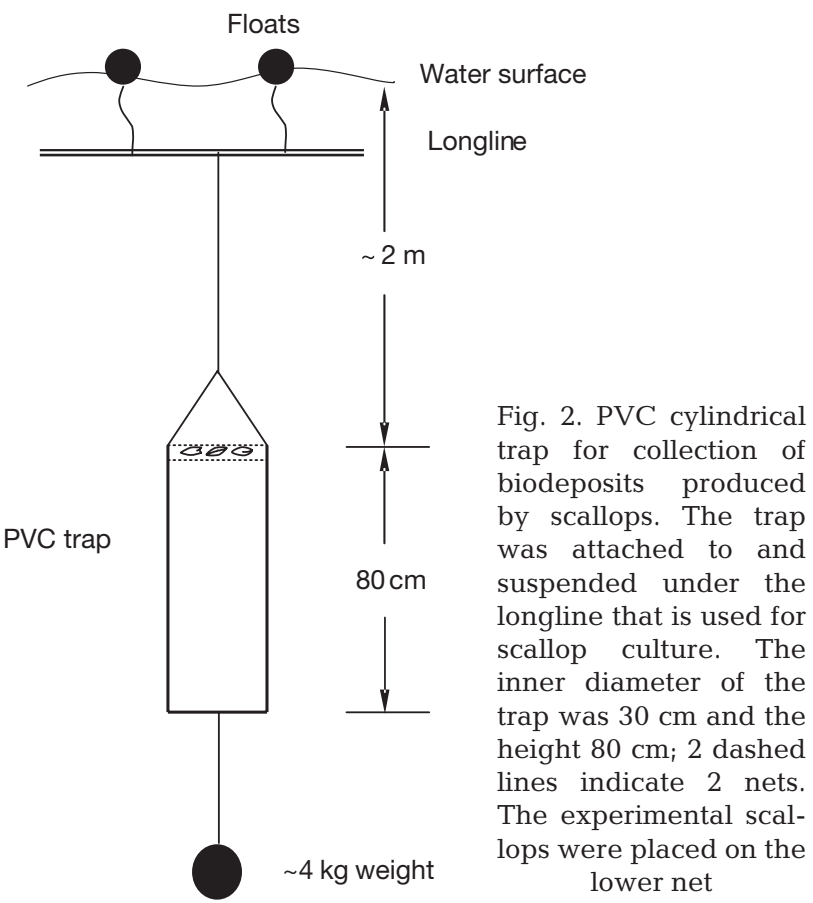

tray of scallop lantern nets, so that deposits from a tray of scallops could be examined in a trap.

The experiment involved 3 treatments with 3 or 4 replicates each. One treatment was designed for 1 -yrold scallops (18 ind.; ca. 10 mo old), the second for 2-yrold scallops (12 ind.; ca. 22 mo old), and the third for a control without scallops. Control traps contained empty scallop shells. The density of the experimental scallops was consistent with that of scallops cultured on a plastic tray of a lantern net. The top of each cylinder was covered by 2 nets ( $20 \mathrm{~mm}$ mesh; Fig. 2), $30 \mathrm{~mm}$ apart for 1-yr-old scallops and $50 \mathrm{~mm}$ apart for 2-yr-old scallops. Natural sedimented material was collected in all the traps, while in those containing scallops, biodeposits produced by scallops were also collected. Biodeposition rate $\left(\mathrm{BDR}_{i} \mathrm{mg}\right.$ ind.$^{-1} \mathrm{~d}^{-1}$ ) was determined based on the amount of material collected from each trap holding scallops and that from the control traps. At the beginning of the experiment, scallops from a culture site in Sishili Bay were randomly selected, cleaned of any fouling epibiota and other material, and placed evenly between the nets. The shell height of 1-yr-old scallops was $41.1 \pm 4.2 \mathrm{~mm}$ (soft tissue dry weight 0.48 $\pm 0.06 \mathrm{~g}$ ind..$\left.^{-1}\right)$, and for 2-yr-old scallops was $60.9 \pm$ $6.2 \mathrm{~mm}$ (soft tissue dry weight $1.91 \pm 0.22 \mathrm{~g}_{\text {ind }} \mathrm{.}^{-1}$ ).

All sediment traps were hung from a longline (no scallops cultivated within a radius of $10 \mathrm{~m}$ ) so that the experimental scallops were at a depth of ca. $2 \mathrm{~m}$, corresponding to routine culture depth of scallops in lantern nets. For determination of sedimentation rates, 3 or 4 traps were deployed on the bottom under scallop lines. 
At Stn S4 (reference), only natural sedimentation at the bottom was determined. After the sediment traps had been deployed for ca. $3 \mathrm{~d}$, they were carefully retrieved from a boat, where the supernatant water in the cylinders was siphoned off. The cylinders were taken to the laboratory where excess water in the sediment was removed by centrifugation and the collected material was rinsed several times with distilled water to remove salts. The sedimented material was then dried at $60^{\circ} \mathrm{C}$ for $4 \mathrm{~d}$ and weighed, and then crushed to a fine powder (100 mesh) with a mortar and pestle. Scallops in each trap were collected and measured (shell height \pm $0.01 \mathrm{~mm}$ ) and dry weight of soft tissue was determined by drying at $60^{\circ} \mathrm{C}$ to constant weight $( \pm 0.01 \mathrm{~g})$.

Subsamples of the dried sediment were used to estimate organic material $(\mathrm{OM})$ by combusting $\left(500^{\circ} \mathrm{C}\right.$ for $4 \mathrm{~h}$ ) dried and pre-weighed samples. Subsamples were treated with $0.2 \mathrm{~mol} \mathrm{l}^{-1} \mathrm{HCl}$ to remove carbonates for analyzing organic carbon (OC) and total nitrogen (TN) with a Perkin Elmer Model 240c CHN analyzer standardized with acetanilide. Subsamples were also analyzed for total phosphorus (TP) and organic phosphorus (OP). TP was determined with our modified method after Solórzano \& Sharp (1980) for particulate total P determination (Zhou et al. 2003). Briefly, ca. $200 \mathrm{mg}$ of dry sediments was accurately weighed with a $30 \times$ $50 \mathrm{~mm}$ weighing bottle, to which $2 \mathrm{ml}$ of $0.1 \mathrm{~mol} \mathrm{l}^{-1}$ $\mathrm{MgCl}_{2}$ was added. The weighing bottle was then dried in an oven at $95^{\circ} \mathrm{C}$ and ignited at $500^{\circ} \mathrm{C}$ for $3 \mathrm{~h}$. After cooling, $10 \mathrm{ml}$ of $0.2 \mathrm{~mol} \mathrm{l}^{-1} \mathrm{HCl}$ was added; the weighing bottle was capped and then transferred to an oven at $80^{\circ} \mathrm{C}$ for $30 \mathrm{~min}$. After extraction of the ignited sediment, the mixture was transferred into $15 \mathrm{ml}$ test-tubes and centrifuged at $540 \times g$; the clarified extracts were then diluted 10 times and analyzed by the molybdenum blue colorimetric method (Grasshoff et al. 1983). Organic phosphorus in the sediment was estimated by the difference in $\mathrm{P}$ content of $0.2 \mathrm{~mol}^{-1} \mathrm{HCl}$ extract of ignited and non-ignited sediment.

In addition, clearance rate $(\mathrm{CR})$ and filtration rate (FR) were indirectly estimated from biodeposition rates, i.e. the biodeposition method (Iglesias et al. 1998), by using inorganic material (ash) content of biodeposits as a quantitative tracer of filtered matter.

In order to eliminate variability in physiological rate caused by size difference, the physiological rate parameters (BDR, CR and FR) were standardized to an equivalent individual according to the following formula: $Y_{\mathrm{s}}=Y_{\mathrm{e}}\left(W_{\mathrm{s}} / W_{\mathrm{e}}\right)^{b}$; where $Y_{\mathrm{s}}=$ physiological rate for a standardized individual, $Y_{\mathrm{e}}=$ uncorrected (measured) physiological rate, $W_{\mathrm{s}}=$ standard weight $(0.48 \mathrm{~g}$ for 1-yr-old scallops and $1.91 \mathrm{~g}$ for 2-yr-old scallops), $W_{\mathrm{e}}=$ observed weight of individual, and $b=$ weight exponent (0.62; Hawkins et al. 2001) for the physiological rate function.
Water column. During the experiment, water samples were collected every day (ca. 10:00 h) for $4 \mathrm{~d}$ at $2 \mathrm{~m}$ depth at each station to determine water temperature, salinity and dissolved oxygen, and were immediately filtered to determine total suspended particulate material (TPM), particulate organic matter (POM), particulate inorganic matter (PIM), particulate carbon (POC), particulate nitrogen (PON), phosphorus (PP) and chlorophyll a $\left(\mathrm{chl} a, \mu \mathrm{g}^{-1}\right)$. For POM and PIM determination, $2 \mathrm{l}$ of each water sample was filtered through pre-weighed and pre-combusted $\left(450^{\circ} \mathrm{C}\right.$ for $6 \mathrm{~h}) \mathrm{GF} / \mathrm{C}$ glass fiber filter. After filtration, the filter was rinsed with $50 \mathrm{ml}$ distilled water to remove salts and dried at $60^{\circ} \mathrm{C}$ for $48 \mathrm{~h}$, and weighed. Later on, the filter was combusted at $450^{\circ} \mathrm{C}$ for $6 \mathrm{~h}$. For POC and PON determinations, 21 of each water sample was also filtered through GF/C filters. The filters was then dried at $60^{\circ} \mathrm{C}$ for $48 \mathrm{~h}$ and analyzed with a Perkin Elmer Model 240c CHN analyzer. PP was determined with our modified method after Solórzano \& Sharp (1980) for particulate total P determination (Zhou et al. 2003). In the modified method, $\mathrm{MgCl}_{2}$ was used as an ashing auxiliary instead of the $\mathrm{MgSO}_{4}$ by Solórzano \& Sharp (1980). Chl a was determined with a Turner fluorometer (Parsons et al. 1992).

Biogeochemical characteristics of bottom surficial sediments. Bottom surficial sediment (triplicates) at every scallop culture site was collected by grab sampler $\left(0.010 \mathrm{~m}^{2}\right)$ for determination of concentrations of organic matter (OM) and acid-volatile sulfide (AVS). For AVS determination, 20 to $30 \mathrm{~g}$ of homogenized sediment from each culture site was fixed with $5 \mathrm{ml}$ $10 \%(\mathrm{w} / \mathrm{v})$ zinc acetate immediately after collection. The sampled sediments were immediately frozen and transported to the laboratory. OM was determined as described above. AVS was determined in the laboratory: the sulfide produced from the sediment in $\mathrm{HCl}$ was removed by an $\mathrm{N}_{2}$ stream and trapped in $20 \mathrm{ml}$ $10 \%(\mathrm{w} / \mathrm{v})$ zinc acetate and the sulfide concentration in the traps then determined by an iodimetric method (Grasshoff et al. 1983, Zhou 2000).

Sediment cores were also collected at Stns S3 (scallop culture site) and $\mathrm{S} 4$ (non-culture site) by divers using SCUBA. The cores (60 mm diameter; $200 \mathrm{~mm}$ long) were collected by gently pushing open-ended Perspex tubes into the sediment to preserve the sediment horizons. The sampled sediments were frozen immediately and transported to the laboratory. The cores were sliced at intervals of $2 \mathrm{~cm}$. Porewater of every slice sample was extracted by centrifugation at $1200 \times g$ for $15 \mathrm{~min}$. After dilution 10 times, pore water was determined for the nutrients $\mathrm{NH}_{4}-\mathrm{N}, \mathrm{NO}_{3}-\mathrm{N}, \mathrm{NO}_{2}$ $\mathrm{N}$ and $\mathrm{PO}_{4}$-P using standard methods as in Grasshoff et al. (1983). $\mathrm{NH}_{4}-\mathrm{N}$ was measured by the indophenol blue method, $\mathrm{NO}_{3}-\mathrm{N}$ by the cadmium-copper reduc- 
tion method, $\mathrm{NO}_{2}-\mathrm{N}$ by the Griess-Ilosvay method, and $\mathrm{PO}_{4}$-P by the phosphomolybdenum blue method. Nutrients were analysed with a continuous flow analyzer (Skalar San Plus System). Slice samples were also determined for AVS as described above.

Statistical analysis. Data were analysed using analysis of variance (ANOVA). A 2-way mixed-model ANOVA (site $\times$ age) was used to determine differences in biodeposition rate, clearance rate and filtration rate. Also, a 2-way mixed-model ANOVA (site $\times$ sediment source) was used to determine differences in chemical composition of scallop biodeposit and naturally sedimented material. If a significant interaction term was found, then a separate 1-way ANOVA was conducted. Prior to analysis, data were examined for homogeneity of variances ( $F$-test). Heterogeneous data were transformed and evaluated using ANOVA. A statistical significance level of 0.05 was used.

\section{RESULTS}

\section{Water column characteristics}

During the study period, salinity in Sishili Bay changed little, ranging from 30.25 to $30.65 \mathrm{ppt}$, as did surface-water temperature $\left(17.8\right.$ to $\left.20.9^{\circ} \mathrm{C}\right), \mathrm{pH}(7.96$ to 8.36) and oxygen concentrations (5.06 to $6.07 \mathrm{ml} \mathrm{l}^{-1}$ ). Seston and chl a concentrations varied markedly among stations, with TPM ranging from 2.02 to $5.03 \mathrm{mg} \mathrm{l}^{-1}$ and chl a from 1.57 to $4.02 \mu \mathrm{g} \mathrm{l}^{-1}$ (Table 1). The variations could be due to differences in environmental conditions, such as geographic location, current flow, water depth and culture activity. Generally, seston concentrations along the coastline of Yantai City were relatively high. Food availability, expressed as POM, also exhibited a great variation among culture sites, ranging from 1.12 to $2.55 \mathrm{mg} \mathrm{l}^{-1}$. At Stn $\mathrm{S} 2$, with a shallow water depth of $5 \mathrm{~m}$, the TPM averaged $5.03 \pm$ $1.24 \mathrm{mg} \mathrm{l}^{-1}$ and was the highest; while at Stns D1, D2 and D3, the TPMs $\left(<3 \mathrm{mg} \mathrm{l}^{-1}\right)$ were significantly lower (1-way ANOVA, $\mathrm{p}<0.01)$. Percentage of organic matter (\%Org.), however, remained fairly constant, ranging from 50.6 to $55.2 \%$. Seston $\mathrm{C} / \mathrm{N}$ ratios in scallop culture sites ranged from 8.8 to 11.5 (mean 10.3), and N/P and C/P ratios averaged 9.8 and 101, respectively (Table 1). At Stn S4, the reference site, the C/N, N/P and $\mathrm{C} / \mathrm{P}$ ratios were slightly lower than at the culture sites.

\section{Biodeposition and natural sedimentation}

A 2-way mixed-model ANOVA showed that scallop biodeposition rates were influenced significantly by both culture site and scallop age $(p<0.01)$, whereas the interaction term was non-significant $(p>0.05)$. The biodeposition rates of 1 -yr-old scallops at 8 culture sites ranged from 33.8 to $133.0 \mathrm{mg}$ dry material ind. ${ }^{-1}$ $\mathrm{d}^{-1}$, with a mean of $77.6(\mathrm{SD}=33.0) \mathrm{mg}$ ind..$^{-1} \mathrm{~d}^{-1}$ (Table 2). The means of OC, ON, TP and OP biodeposition rates for 1-yr-old scallops were $4.00 \pm 1.80,0.51 \pm$ $0.19,0.11 \pm 0.05$ and $0.028 \pm 0.012 \mathrm{mg}$ ind..$^{-1} \mathrm{~d}^{-1}$, respectively. The biodeposition rate at Stn $\mathrm{S} 2$ was the highest $\left(133.0 \pm 25.5 \mathrm{mg}\right.$ ind..$\left.^{-1} \mathrm{~d}^{-1}\right)$, while, rates at Stns D1, D2 and D3 $\left(<50 \mathrm{mg}\right.$ ind..$\left.^{-1} \mathrm{~d}^{-1}\right)$ were significantly lower than those at other culture sites $(p<0.01)$. Fig. 3 indicates that the biodeposition rates of 1 -yr-old scallops $\left(\mathrm{BDR}_{;} \mathrm{mg}\right.$ ind. $\left.{ }^{-1} \mathrm{~d}^{-1}\right)$ were correlated positively with seston concentrations $\left(\mathrm{TPM}_{i} \mathrm{mg} \mathrm{l}^{-1}\right.$ ), and their relationship can be expressed as follows: $\mathrm{BDR}=$ 101.11 Ln (TPM) - $41.311\left(\mathrm{R}^{2}=0.950 ; \mathrm{n}=8 ; \mathrm{p}<0.01\right)$.

Table 1. Total suspended particulate matter and its chemical composition in the water column at scallop culture sites in Sishili Bay (means $\pm \mathrm{SD} ; \mathrm{n}=4$ ). TPM: total suspended particulate matter; POM: particulate organic matter; POC: particulate organic carbon; PON: particulate organic nitrogen; PP: particulate phosphorus; \%Org.: percentage of organic matter; chl a: chlorophyll $a$

\begin{tabular}{|c|c|c|c|c|c|c|c|c|c|c|}
\hline Station & $\begin{array}{c}\text { TPM } \\
\left(\mathrm{mg} \mathrm{l}^{-1}\right)\end{array}$ & $\begin{array}{c}\mathrm{POM} \\
\left(\mathrm{mg} \mathrm{l}^{-1}\right)\end{array}$ & $\begin{array}{c}\mathrm{POC} \\
\left(\mathrm{mg} \mathrm{l}^{-1}\right)\end{array}$ & $\begin{array}{c}\text { PON } \\
\left(\mu \mathrm{g} \mathrm{l}^{-1}\right)\end{array}$ & $\begin{array}{c}\mathrm{PP} \\
\left(\mu \mathrm{g} \mathrm{l}^{-1}\right)\end{array}$ & $\%$ Org. & $\mathrm{C} / \mathrm{N}$ & $\mathrm{N} / \mathrm{P}$ & $\mathrm{C} / \mathrm{P}$ & $\begin{array}{c}\mathrm{Chl} a \\
\left(\mu \mathrm{g}^{-1}\right)\end{array}$ \\
\hline D1 & $2.02 \pm 0.43$ & $1.12 \pm 0.20$ & $0.41 \pm 0.06$ & $54.6 \pm 9.2$ & $12.2 \pm 2.1$ & $55.2 \pm 10.4$ & $8.8 \pm 1.5$ & $9.9 \pm 2.4$ & $87 \pm 15$ & $1.71 \pm 0.32$ \\
\hline D2 & $2.58 \pm 0.55$ & $1.38 \pm 0.26$ & $0.53 \pm 0.10$ & $54.4 \pm 9.8$ & $15.3 \pm 2.8$ & $53.4 \pm 10.5$ & $11.5 \pm 1.9$ & $7.8 \pm 1.5$ & $90 \pm 14$ & $2.23 \pm 0.47$ \\
\hline D3 & $2.25 \pm 0.49$ & $1.18 \pm 0.21$ & $0.44 \pm 0.07$ & $55.6 \pm 9.4$ & $11.3 \pm 2.0$ & $52.3 \pm 10.3$ & $9.2 \pm 1.4$ & $10.9 \pm 2.3$ & $101 \pm 15$ & $1.57 \pm 0.37$ \\
\hline D4 & $3.55 \pm 0.72$ & $1.83 \pm 0.37$ & $0.65 \pm 0.13$ & $72.6 \pm 14.5$ & $15.2 \pm 3.1$ & $51.6 \pm 10.8$ & $10.4 \pm 2.0$ & $10.6 \pm 3.0$ & $110 \pm 22$ & $2.40 \pm 0.43$ \\
\hline $\mathrm{S} 1$ & $3.90 \pm 0.83$ & $2.06 \pm 0.43$ & $0.84 \pm 0.19$ & $108.2 \pm 22.5$ & $21.0 \pm 4.5$ & $52.9 \pm 11.1$ & $9.0 \pm 2.0$ & $11.4 \pm 3.4$ & $103 \pm 23$ & $4.02 \pm 0.94$ \\
\hline $\mathrm{S} 2$ & $5.03 \pm 1.24$ & $2.55 \pm 0.56$ & $1.01 \pm 0.23$ & $104.0 \pm 22.9$ & $24.9 \pm 5.6$ & $50.6 \pm 11.9$ & $11.4 \pm 2.5$ & $9.2 \pm 3.1$ & $105 \pm 24$ & $3.64 \pm 0.98$ \\
\hline S3 & $4.04 \pm 1.01$ & $2.07 \pm 0.44$ & $0.83 \pm 0.18$ & $89.6 \pm 19.2$ & $20.3 \pm 4.4$ & $51.2 \pm 11.6$ & $10.8 \pm 2.1$ & $9.8 \pm 2.9$ & $106 \pm 22$ & $3.15 \pm 0.79$ \\
\hline $\mathrm{S} 4^{\mathrm{a}}$ & $3.86 \pm 0.87$ & $2.05 \pm 0.40$ & $0.82 \pm 0.16$ & $99.5 \pm 20.7$ & $22.3 \pm 4.9$ & $53.1 \pm 11.2$ & $9.6 \pm 1.7$ & $9.9 \pm 1.8$ & $95 \pm 19$ & $2.97 \pm 0.65$ \\
\hline S5 & $3.70 \pm 0.77$ & $2.00 \pm 0.42$ & $0.70 \pm 0.15$ & $70.8 \pm 14.5$ & $17.6 \pm 3.8$ & $54.1 \pm 11.3$ & $11.5 \pm 1.5$ & $8.9 \pm 2.2$ & $102 \pm 21$ & $2.90 \pm 0.68$ \\
\hline Mean $^{b}$ & $3.39 \pm 1.02$ & $1.77 \pm 0.49$ & $0.68 \pm 0.21$ & $76.2 \pm 21.9$ & $17.2 \pm 4.6$ & $52.7 \pm 11.0$ & $10.3 \pm 1.1$ & $9.8 \pm 1.2$ & $101 \pm 8$ & $2.71 \pm 0.84$ \\
\hline
\end{tabular}


Table 2. Chlamys farreri. Biodeposition rates $\left(\mathrm{mg}\right.$ ind.$^{-1} \mathrm{~d}^{-1}$; means $\pm \mathrm{SD}$ ) at different scallop culture sites in Sishili Bay. OM: organic material; OC: organic carbon; ON: organic nitrogen; TP: total phosphorus; OP: organic phosphorus

\begin{tabular}{|c|c|c|c|c|c|c|c|}
\hline Station & $\begin{array}{l}\text { Scallop } \\
\text { age (yr) }\end{array}$ & Dry material & $\mathrm{OM}$ & $\mathrm{OC}$ & ON & TP & $\mathrm{OP}$ \\
\hline D1 & $\begin{array}{l}1 \\
2\end{array}$ & $\begin{array}{l}33.8 \pm 3.4 \\
84.6 \pm 11.1\end{array}$ & $\begin{array}{l}4.74 \pm 0.54 \\
9.01 \pm 1.13\end{array}$ & $\begin{array}{l}2.26 \pm 0.24 \\
3.35 \pm 0.42\end{array}$ & $\begin{array}{l}0.33 \pm 0.04 \\
0.49 \pm 0.06\end{array}$ & $\begin{array}{l}0.07 \pm 0.01 \\
0.12 \pm 0.01\end{array}$ & $\begin{array}{l}0.012 \pm 0.002 \\
0.020 \pm 0.003\end{array}$ \\
\hline D2 & 1 & $47.9 \pm 5.9$ & $4.97 \pm 0.59$ & $2.15 \pm 0.25$ & $0.28 \pm 0.04$ & $0.06 \pm 0.01$ & $0.019 \pm 0.003$ \\
\hline D3 & $\begin{array}{l}1 \\
2\end{array}$ & $\begin{array}{l}45.3 \pm 6.0 \\
94.3 \pm 11.4\end{array}$ & $\begin{array}{r}5.16 \pm 0.70 \\
10.83 \pm 1.38\end{array}$ & $\begin{array}{l}1.88 \pm 0.23 \\
4.13 \pm 0.51\end{array}$ & $\begin{array}{l}0.30 \pm 0.04 \\
0.68 \pm 0.07\end{array}$ & $\begin{array}{l}0.06 \pm 0.01 \\
0.12 \pm 0.01\end{array}$ & $\begin{array}{l}0.013 \pm 0.002 \\
0.028 \pm 0.003\end{array}$ \\
\hline D4 & $\begin{array}{l}1 \\
2\end{array}$ & $\begin{array}{r}93.3 \pm 14.8 \\
181.5 \pm 31.6\end{array}$ & $\begin{array}{r}9.29 \pm 1.38 \\
18.32 \pm 3.13\end{array}$ & $\begin{array}{l}4.01 \pm 0.63 \\
7.29 \pm 1.21\end{array}$ & $\begin{array}{l}0.65 \pm 0.11 \\
1.08 \pm 0.18\end{array}$ & $\begin{array}{l}0.11 \pm 0.02 \\
0.22 \pm 0.04\end{array}$ & $\begin{array}{l}0.035 \pm 0.006 \\
0.062 \pm 0.010\end{array}$ \\
\hline S1 & $\begin{array}{l}1 \\
2\end{array}$ & $\begin{array}{r}88.6 \pm 13.1 \\
166.4 \pm 26.1\end{array}$ & $\begin{array}{r}9.22 \pm 1.43 \\
17.28 \pm 2.61\end{array}$ & $\begin{array}{l}4.19 \pm 0.64 \\
6.97 \pm 1.11\end{array}$ & $\begin{array}{l}0.49 \pm 0.07 \\
0.95 \pm 0.15\end{array}$ & $\begin{array}{l}0.10 \pm 0.02 \\
0.22 \pm 0.03\end{array}$ & $\begin{array}{l}0.036 \pm 0.005 \\
0.051 \pm 0.008\end{array}$ \\
\hline $\mathrm{S} 2$ & 1 & $133.0 \pm 25.5$ & $16.39 \pm 3.18$ & $6.68 \pm 1.24$ & $0.77 \pm 0.16$ & $0.17 \pm 0.04$ & $0.039 \pm 0.008$ \\
\hline S3 & 1 & $95.6 \pm 12.8$ & $12.64 \pm 1.63$ & $5.86 \pm 0.80$ & $0.68 \pm 0.10$ & $0.21 \pm 0.03$ & $0.036 \pm 0.006$ \\
\hline S5 & $\begin{array}{l}1 \\
2\end{array}$ & $\begin{array}{r}83.5 \pm 11.5 \\
175.8 \pm 21.3\end{array}$ & $\begin{array}{r}9.50 \pm 1.27 \\
20.84 \pm 2.63\end{array}$ & $\begin{array}{l}4.97 \pm 0.67 \\
9.26 \pm 1.15\end{array}$ & $\begin{array}{l}0.58 \pm 0.08 \\
1.05 \pm 0.13\end{array}$ & $\begin{array}{l}0.13 \pm 0.02 \\
0.28 \pm 0.04\end{array}$ & $\begin{array}{l}0.037 \pm 0.005 \\
0.098 \pm 0.013\end{array}$ \\
\hline Mean & $\begin{array}{l}1 \\
2\end{array}$ & $\begin{array}{r}77.6 \pm 33.0 \\
140.5 \pm 47.1\end{array}$ & $\begin{array}{r}8.99 \pm 4.10 \\
15.25 \pm 5.09\end{array}$ & $\begin{array}{l}4.00 \pm 1.80 \\
6.20 \pm 2.42\end{array}$ & $\begin{array}{l}0.51 \pm 0.19 \\
0.85 \pm 0.26\end{array}$ & $\begin{array}{l}0.11 \pm 0.05 \\
0.19 \pm 0.07\end{array}$ & $\begin{array}{l}0.028 \pm 0.012 \\
0.052 \pm 0.031\end{array}$ \\
\hline
\end{tabular}

Biodeposition rates of 2-yr-old scallops also exhibited a marked variability among culture sites (Table 2, Fig. 3). At Stns S1, S5 and D4, the biodeposition rates of 2yr-old individuals $(166.4 \pm 26.1,175.8 \pm 21.3$, and 181.5 $\pm 31.6 \mathrm{mg}$ ind ${ }^{-1} \mathrm{~d}^{-1}$, respectively) were significantly higher than those at Stns D1 and D3 (84.6 \pm 10.9 and $94.3 \pm 11.4 \mathrm{mg}$ ind. ${ }^{-1} \mathrm{~d}^{-1}$, respectively). The biodeposition rates of the 2-yr-old scallops were approximately twice those of 1-yr-old individuals (Table 2).

At scallop culture sites, sedimentation rates ranged from 16.5 to $36.7 \mathrm{~g}$ dry material $\mathrm{m}^{-2} \mathrm{~d}^{-1}$ (mean $24.1 \pm$ $7.3 \mathrm{~g} \mathrm{~m}^{-2} \mathrm{~d}^{-1}$ ) and were significantly higher than at the non-culture site $\left(9.8 \pm 2.1 \mathrm{~g} \mathrm{~m}^{-2} \mathrm{~d}^{-1}\right.$; 1 -way ANOVA, $\mathrm{p}<0.01$; Fig. 4), by a factor of 1.68 to 3.74 (mean 2.46). Sedimentation rates among culture sites exhibited a

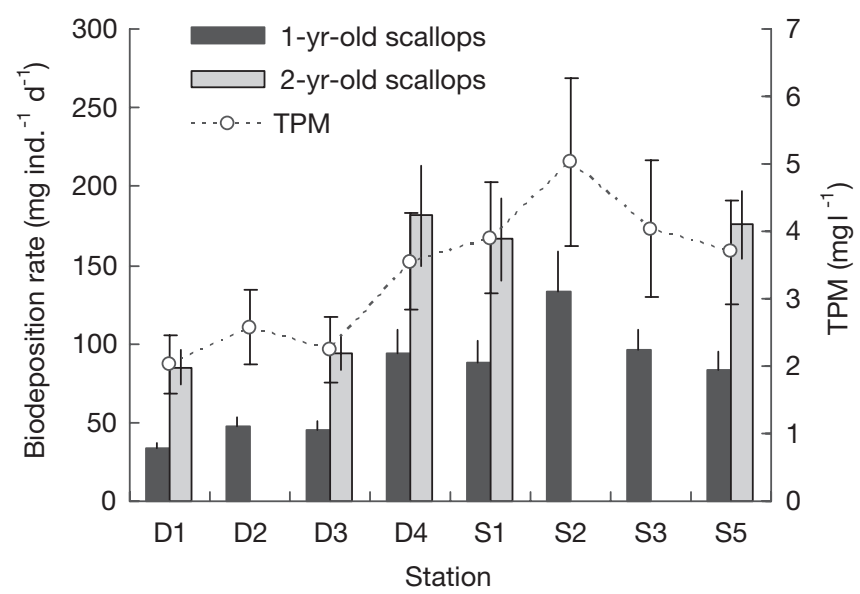

Fig. 3. Chlamys farreri. Relationship between biodeposition rates (mg ind ${ }^{-1} \mathrm{~d}^{-1}$; means $\pm \mathrm{SD}$ ) of the Zhikong scallop and concentrations of total suspended particulate matter (TPM; $\mathrm{mg} \mathrm{l}^{-1}$; means $\pm \mathrm{SD}$ ) in the water column in Sishili Bay considerable variability, with rates at Stns D1, D2 and D3 generally lower than other culture sites ( $p<0.05)$.

The chemical composition (OM, OC, ON and OP) of scallop biodeposit and sediment is shown in Fig. 5. Although the mean OM $(11.54 \%$; Table 3$)$ in biodeposits of 1-yr-old scallops was slightly higher than in the control sediment, there was no statistically significant difference in the chemical composition between scallop biodeposit and sediment (2-way ANOVA, p > 0.05). In general, scallop biodeposit contained significantly more organic matter and $\mathrm{C}, \mathrm{N}$ and $\mathrm{P}$ than sediment (2-way ANOVA, p < 0.05; Fig. 4, Table 3). OP percentage in TP in scallop biodeposit (mean $25.8 \%$ ) was significantly higher than that in natural sediment $(19.8 \%$; Table 3 ; p < 0.05). OM, OC, ON and OP in sediment at culture site bottoms were generally higher than those at the non-culture site (Fig. 4, Table 3).

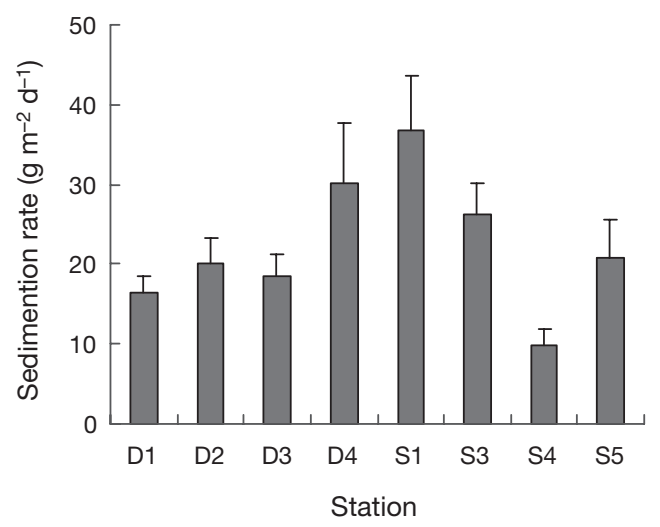

Fig. 4. Sedimentation rates $\left(\mathrm{g} \mathrm{m}^{-2} \mathrm{~d}^{-1}\right.$; means $\left.\pm \mathrm{SD}\right)$ at the culture sites and at the reference site (S4) 

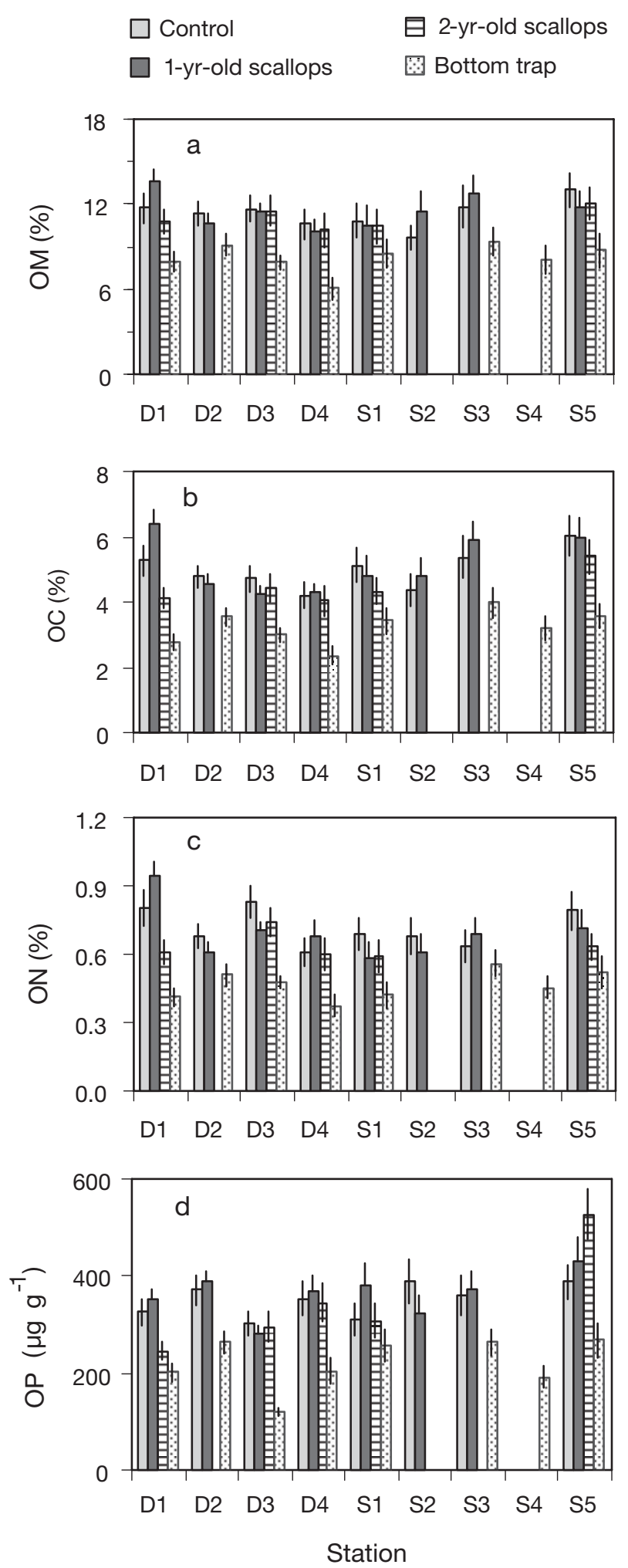

Fig. 5. (a) Organic matter (OM), (b) organic carbon (OC), (c) organic nitrogen (ON) and (d) organic phosphorus (OP) contents in sediments collected in the traps, including the control (without scallops) and the traps with 1-yr-old scallops or 2-yrold scallops. Values are means \pm SD
Scallop clearance rates (CR) and filtration rates (FR) were influenced significantly by both culture site and scallop age (2-way mixed-model ANOVA; p < 0.01), whereas the interaction term was non-significant $(\mathrm{p}>$ 0.05). Table 4 shows that clearance rates of 1 -yr-old scallops among 8 culture sites ranged from 1.33 to $2.04 \mathrm{lind} .^{-1} \mathrm{~h}^{-1}$ (mean $1.72 \pm 0.23 \mathrm{lind} .^{-1} \mathrm{~h}^{-1}$ ), and were positively correlated with seston concentrations ( $\mathrm{CR}=$ 0.1961 TPM + 1.0531; $\left.\mathrm{R}^{2}=0.6916 ; \mathrm{n}=8 ; \mathrm{p}<0.05\right)$. Filtration rates of 1 -yr-old scallops exhibited a great variability among culture sites, ranging from 2.70 to $9.84 \mathrm{mg}$ ind. ${ }^{-1} \mathrm{~h}^{-1}$ (mean $5.99 \pm 2.26 \mathrm{mg}$ ind. ${ }^{-1} \mathrm{~h}^{-1}$; Table 4). Fig. 6 clearly shows that FR had a positive correlation with seston concentration, which could be expressed as follows: $\mathrm{FR}=2.327 \mathrm{TPM}-1.883\left(\mathrm{R}^{2}=\right.$ $0.974 ; \mathrm{n}=8 ; \mathrm{p}<0.01)$. For 2 -yr-old scallops, $\mathrm{CR}$ ranged from 3.24 to $3.96 \mathrm{l}$ ind. $^{-1} \mathrm{~h}^{-1}$ (mean $3.57 \mathrm{lind}^{-1} \mathrm{~h}^{-1}$; Table 4), and FR from 7.03 to $14.07 \mathrm{mg}$ ind. ${ }^{-1} \mathrm{~h}^{-1}$ (mean $11.13 \mathrm{mg}$ ind. ${ }^{-1} \mathrm{~h}^{-1}$ ). Both CRs and FRs were markedly higher than those of 1-yr-old scallops.

\section{Sediment biogeochemical characteristics}

Generally, sediments under scallop cultures (especially at Stns S1, S2, S3, S5) showed finer texture and darker color than at the adjacent reference station (S4). Organic matter in all sediments was generally low, ranging from 1.03 to $2.24 \%$ (Fig. 7). Sediments at culture sites contained more organic matter that at the control site. Especially at Stns S1, S2, S3 and S5, organic matter percentages were markedly higher than that at the control station (S4; 1-way ANOVA, p < 0.05).

Acid-volatile sulfides (AVS) were generally at low levels at all sites (Fig. 7), with AVS-S ranging from 45.8 to $186.5 \mathrm{\mu g} \mathrm{g}^{-1}$. There was a positive relationship between OM (\%) and AVS-S ( $\mathrm{gg} \mathrm{g}^{-1}$ ) in sediments (AVS-

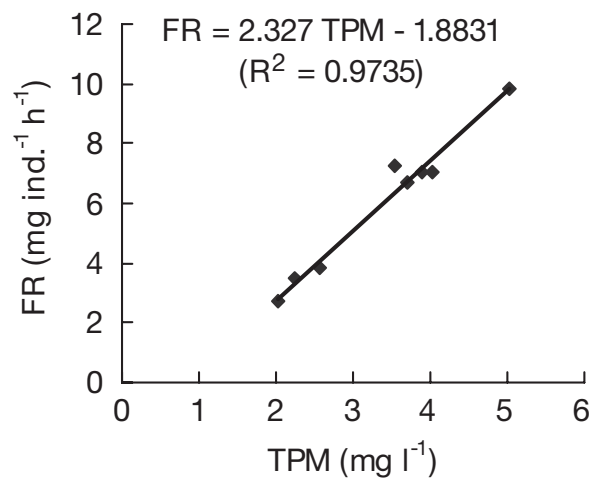

Fig. 6. Chlamys farreri. Relationship between filtering rates $\left(\mathrm{FR}_{i}\right.$ mg ind. ${ }^{-1} \mathrm{~d}^{-1}$ ) of the Zhikong scallop and concentrations of total suspended particulate matter $\left(\mathrm{TPM} \mathrm{mg} \mathrm{l}^{-1}\right)$ in the water column 
Table 3. Means of $\mathrm{C}, \mathrm{N}$ and $\mathrm{P}$ contents in scallop biodeposits and sediments from traps deployed on the botttom. OM: organic matter; OC: organic carbon; ON: organic nitrogen; TP: total phosphorus; OP: organic phosphorus

\begin{tabular}{|lccccccccc|}
\hline Sediments & OM (\%) & OC (\%) & ON (\%) & TP (\%) & OP (\%) & C/N & C/OP & N/OP & OP/TP (\%) \\
\hline Biodeposit traps & & & & & & & & & \\
Control (no scallops) & 11.33 & 4.98 & 0.71 & 0.129 & 0.035 & 8.19 & 371 & 53.4 & 27.3 \\
1-yr-old scallops & 11.54 & 5.13 & 0.69 & 0.144 & 0.036 & 8.72 & 368 & 50.1 & 26.0 \\
2-yr-old scallops & 10.99 & 4.47 & 0.63 & 0.135 & 0.034 & 8.26 & 351 & 50.9 & 25.3 \\
Bottom sediment traps & & & & & & & & & \\
Under culture sites & 8.23 & 3.24 & 0.47 & 0.113 & 0.022 & 8.09 & 386 & 59.6 & 19.8 \\
Under non-culture site & 8.12 & 3.21 & 0.45 & 0.098 & 0.019 & 8.25 & 432 & 61.1 & 19.6 \\
\hline
\end{tabular}

$\left.\mathrm{S}=187.8 \mathrm{Ln} \mathrm{OM}+27.482 ; \mathrm{R}^{2}=0.876 ; \mathrm{n}=8 ; \mathrm{p}<0.05\right)$. At the shallow culture sites, Stns S1, S2, S3 and S5, AVS-S concentrations were $>100 \mu \mathrm{g} \mathrm{g}^{-1}$, and were sig-

Table 4. Chlamys farreri. Clearance rates (means $\pm \mathrm{SD}$ ) and filtration rates (means $\pm \mathrm{SD}$ ) of Zhikong scallops suspensioncultured in Sishili Bay

\begin{tabular}{|lccc|}
\hline Station & $\begin{array}{c}\text { Scallop } \\
\text { age (yr) }\end{array}$ & $\begin{array}{c}\text { CR } \\
\left(1 \text { ind }^{-1} \mathrm{~h}^{-1}\right)\end{array}$ & $\begin{array}{c}\text { FR } \\
\left(\text { mg ind }^{-1} \mathrm{~h}^{-1}\right)\end{array}$ \\
\hline D1 & 1 & $1.33 \pm 0.24$ & $2.70 \pm 0.51$ \\
& 2 & $3.46 \pm 0.66$ & $7.03 \pm 1.5$ \\
D2 & 1 & $1.49 \pm 0.28$ & $3.83 \pm 0.77$ \\
D3 & 1 & $1.56 \pm 0.29$ & $3.51 \pm 0.61$ \\
& 2 & $3.24 \pm 0.54$ & $7.29 \pm 1.4$ \\
D4 & 1 & $2.04 \pm 0.41$ & $7.24 \pm 1.59$ \\
& 2 & $3.96 \pm 0.83$ & $14.05 \pm 3.1$ \\
S1 & 1 & $1.80 \pm 0.40$ & $7.02 \pm 1.47$ \\
& 2 & $3.38 \pm 0.74$ & $13.19 \pm 3.0$ \\
S2 & 1 & $1.96 \pm 0.45$ & $9.84 \pm 1.92$ \\
S3 & 1 & $1.75 \pm 0.33$ & $7.08 \pm 1.61$ \\
S5 & 1 & $1.81 \pm 0.38$ & $6.71 \pm 1.54$ \\
& 2 & $3.80 \pm 0.87$ & $14.07 \pm 3.4$ \\
Mean & 1 & $1.72 \pm 0.23$ & $5.99 \pm 2.26$ \\
& 2 & $3.57 \pm 0.27$ & $11.13 \pm 3.25$ \\
\hline
\end{tabular}

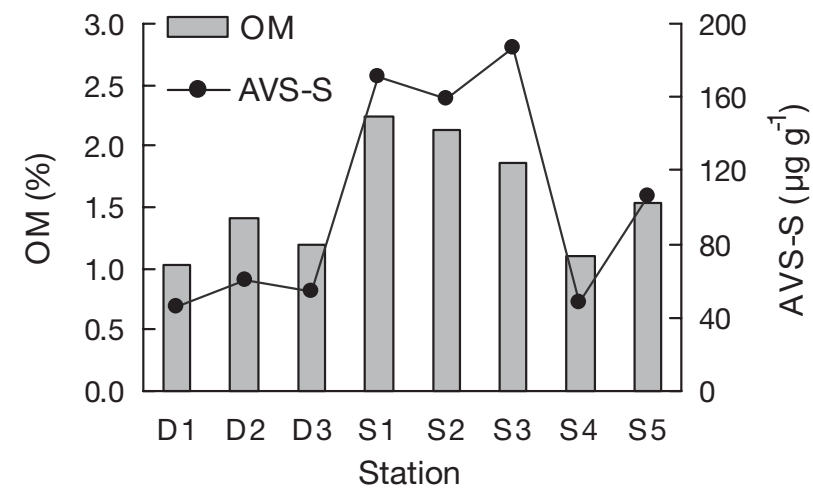

Fig. 7. Content of organic matter $\left(\mathrm{OM}_{i} \%\right)$ and acid-volatile sulfide (AVS-S; $\mu \mathrm{g} \mathrm{g}^{-1}$ ) in the sediments at scallop culture sites and the reference site (Stn S4). Values are means nificantly higher than that at the control site $(47.6 \mu \mathrm{g}$ $\mathrm{g}^{-1}$; $\mathrm{p}<0.01$ ), indicating a partial shift toward anaerobiosis at these culture sites. However, the concentration of AVS-S in the top $4 \mathrm{~cm}$ of the cores from both the culture site Stn S3 and the control site Stn S4 was relatively low, 30 to $60 \mu \mathrm{g} \mathrm{g}^{-1}$, indicating that surface sediments were oxic, even under scallop culture sites.

Fig. 8 shows the mean nutrient $\left(\mathrm{NH}_{4}-\mathrm{N}, \mathrm{NO}_{3}-\mathrm{N}\right.$, $\mathrm{NO}_{2}-\mathrm{N}$ and $\mathrm{PO}_{4}-\mathrm{P}$ ) concentrations in porewaters of the core samples from a culture site (S3) and the control site (S4). $\mathrm{NH}_{4}-\mathrm{N}$ at $\mathrm{Stn} \mathrm{S} 3\left(366 \pm 150 \mu \mathrm{mol} \mathrm{l} \mathrm{l}^{-1}\right)$ was significantly higher than that at Stn S4 $\left(163 \pm 69 \mu \mathrm{mol} \mathrm{l}^{-1}\right.$; 1 -way ANOVA, $\mathrm{p}<0.01$ ); and $\mathrm{NO}_{3}-\mathrm{N}, \mathrm{NO}_{2}-\mathrm{N}$ and $\mathrm{PO}_{4}$ -
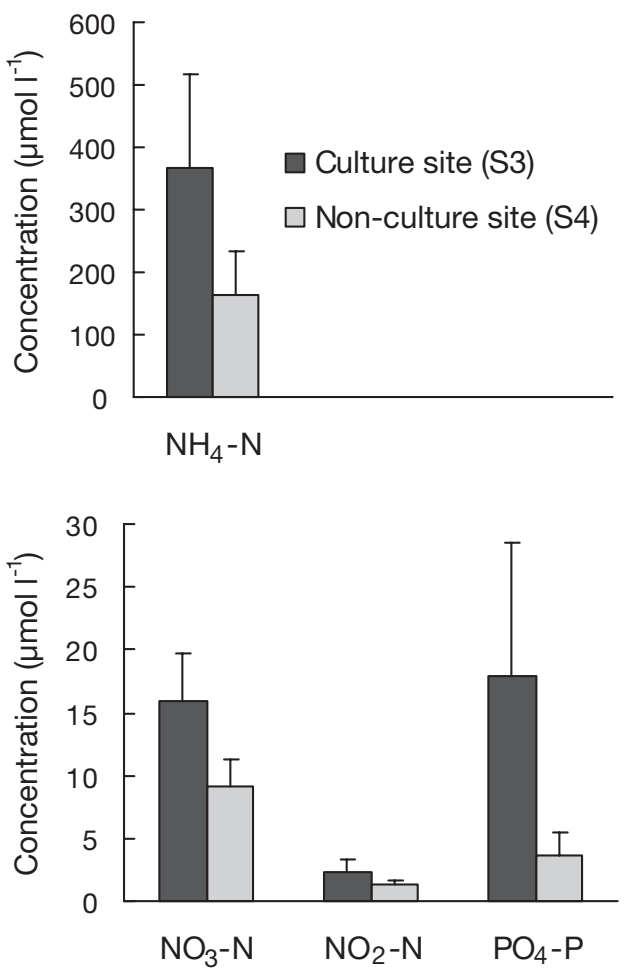

Fig. 8. Nutrient concentrations $\left(\mathrm{NH}_{4}-\mathrm{N}, \mathrm{NO}_{3}-\mathrm{N}, \mathrm{NO}_{2}-\mathrm{N}\right.$ and $\mathrm{PO}_{4}-\mathrm{P}_{;} \mu \mathrm{mol} \mathrm{l} \mathrm{l}^{-1}$ ) in sediment porewaters at a scallop culture site (Stn S3) and the reference site (Stn S4). Values are means $\pm \mathrm{SD}$ 
$\mathrm{P}$ at Stn S3 were also significantly higher than those at the control site Stn S4 ( $<<0.05)$.

\section{DISCUSSION}

The biodeposition rates of Chlamys farreri varied greatly among culture sites in Shishili Bay. The spatial variations can be mainly attributed to the spatial variations in food availability. The positive correlation between scallop biodeposition rate and seston concentration was in agreement with previous laboratoryexperimental studies (Haven \& Morales-Alamo 1966, Tenore \& Dunstan 1973, Klerks et al. 1996). Tenore \& Dunstan (1973) showed that the biodeposition rates of Mytilus edulis, Crassostrea virginica and Mercenaria mercenaria increased logarithmically with increased seston concentration. Likewise, Klerks et al. (1996) showed a positive relationship between biodeposition rate and seston concentration for the zebra mussel Dreissena polymorpha. Our recent study in field flowthrough systems $\left(10 \mathrm{~m}^{3}\right.$ biotanks) conducted in Shishili Bay also showed that the biodeposition rate of $C$. farreri was positively correlated to seston concentration (Zhou et al. 2006a).

Most forms of bivalve shellfish cultures contribute to enhanced sedimentation of organic material proximal to the culture units (Dahlbäck \& Gunarsson 1981, Tenore et al. 1982, Kaspar et al. 1985, Hatcher et al. 1994, Grant et al. 1995). This work showed that suspension-cultured scallops could also greatly increase the deposition. Sedimentation rates in scallop culture sites were 1.68 to 3.74 (mean 2.46) times that in the reference site with no scallop cultured; and the carbon, nitrogen and phosphorus inputs via sedimentation in the culture site were approximately 2.66, 2.72 and 3.04 times, respectively, that at the reference site. Results also demonstrated that scallops had more influence on their local environment than on surrounding sites. Strong filtering-biodeposition process by the intensively cultured Chlamys farreri significantly increased sedimentation of suspended particulate organic matter and particulate-bound nutrients, indicating that the suspended scallops could enhance pelagic-benthic coupling. A study with oysters Crassostrea virginica reported biodeposition rates that were 6 times the normal sedimentation rates (Haven \& Morales-Alamo 1966). Ahn (1993) reported a rate of biodeposition by the bivalve Laternula elliptica that roughly equaled normal sedimentation rate. Grant et al. (1995) observed that sedimentation rate under mussel (Mytilus edulis, M. trossulus) lines averaged 2.4 times that in an adjacent reference site.

The enhancement of sediment organic matter concentration by scallops was not consistent. Grant et al.
(1995) observed that bottom sediments at a mussel culture site and a reference site had similar carbon content, and suggested that organic loading does not connote sediment enrichment in the sense of organically enhanced deposits but in terms of greater absolute carbon deposition, driven in this case by bulk sedimentation. Although the enrichment in mussel biodeposits has been reported in previous studies (Kaspar et al. 1985), the increase in sediment organic matter concentration is not always a consistent result (Jaramillo et al. 1992). Grenz et al. (1990) found that the effects of mussel biodeposition on sediment organic matter were confounded by deposition of bloom phytoplankton.

In Sishili Bay, biodeposition rates of 2-yr-old scallops were almost twice those of 1-yr-old scallops (Table 2). The scallop biodeposition rates fall well within the ranges reported previously for other filter-feeding bivalves (Table 5). Results could be used to estimate biodeposition rates of total scallops cultured in the whole bay. In Sishili Bay, Chlamys farreri was cultured at a density of ca. 350 ind. lantern net ${ }^{-1}$ (covering $0.6 \times$ $5=3 \mathrm{~m}^{2}$ lantern net ${ }^{-1}$ ) in culture sites, or ca. 120 ind. $\mathrm{m}^{-2}$. Based on the result of the mean biodeposition rate of 1-yr-old scallops $(41.1 \pm 4.2 \mathrm{~mm}$ shell height), the daily biodeposit production by the Zhikong scallops in

Table 5. Comparision of bivalve biodeposition rates (modified after Table 3 in Zhou et al. 2006a)

\begin{tabular}{|c|c|c|c|}
\hline Species & \multicolumn{2}{|c|}{$\begin{array}{l}\text { Biodeposition rate } \\
\left(\mathrm{mg}(\mathrm{g} \text { tissue dry } \mathrm{wt})^{-1} \mathrm{~d}^{-1}\right)\end{array}$} & Source \\
\hline $\begin{array}{c}\text { Mytilus } \\
\text { edulis }\end{array}$ & $\begin{array}{l}\text { Dry wt } \\
\text { C } \\
\mathrm{N} \\
\mathrm{P}\end{array}$ & $\begin{array}{c}42.4 \\
3.88 \\
0.505 \\
5.49 \times 10^{-2}\end{array}$ & $\begin{array}{l}\text { Kautsky \& } \\
\text { Evans (1987) }\end{array}$ \\
\hline $\begin{array}{l}\text { Choromytilus } \\
\text { chorus }\end{array}$ & $\begin{array}{l}\text { Dry wt } \\
\mathrm{C} \\
\mathrm{N}\end{array}$ & $\begin{array}{l}689 \\
44.1 \\
2.07\end{array}$ & $\begin{array}{l}\text { Jaramillo et } \\
\text { al. (1992) }\end{array}$ \\
\hline $\begin{array}{l}\text { Mytilus } \\
\text { chilensis }\end{array}$ & $\begin{array}{l}\text { Dry wt } \\
\mathrm{C} \\
\mathrm{N}\end{array}$ & $\begin{array}{l}595 \\
35.7 \\
2.38\end{array}$ & $\begin{array}{l}\text { Jaramillo et } \\
\text { al. (1992) }\end{array}$ \\
\hline $\begin{array}{l}\text { Modiolus } \\
\text { demissus }\end{array}$ & $\mathrm{N}$ & 1.2 & $\begin{array}{l}\text { Jordan \& } \\
\text { Valiela (1982) }\end{array}$ \\
\hline $\begin{array}{l}\text { Modiolus } \\
\text { americanus }\end{array}$ & $\begin{array}{l}\text { Dry wt } \\
\text { C } \\
\mathrm{N} \\
\mathrm{P}\end{array}$ & $\begin{array}{c}2.25 \times 10^{3} \\
24.8 \\
2.47 \\
8.16 \times 10^{-2}\end{array}$ & $\begin{array}{l}\text { Peterson \& } \\
\text { Heck (1999) }\end{array}$ \\
\hline $\begin{array}{l}\text { Chlamys } \\
\text { farreri }\end{array}$ & $\begin{array}{l}\text { Dry wt } \\
\text { C } \\
\text { N } \\
\text { P }\end{array}$ & $\begin{array}{c}173.1 \\
6.8 \\
0.86 \\
0.22\end{array}$ & $\begin{array}{l}\text { Zhou et al. } \\
\text { (2006a) }\end{array}$ \\
\hline $\begin{array}{l}\text { Chlamys } \\
\text { farreri }\end{array}$ & $\begin{array}{l}\text { Dry wt } \\
\text { C } \\
\mathrm{N} \\
\mathrm{P}\end{array}$ & $\begin{array}{c}122.3 \\
6.3 \\
0.80 \\
0.17\end{array}$ & Present study \\
\hline
\end{tabular}


summer amounted to $9.05 \mathrm{~g} \mathrm{~m}^{-2}$, and daily $\mathrm{C}, \mathrm{N}$ and $\mathrm{P}$ biodeposition rates were $4.67 \times 10^{-1}, 5.95 \times 10^{-2}$, $1.32 \times 10^{-2}$ and $3.30 \times 10^{-3} \mathrm{~g} \mathrm{~m}^{-2}$, respectively; for total scallops cultured in the bay (ca. $2.7 \times 10^{9}$ individuals), the daily biodeposition rate was $210 \mathrm{t}$ dry material, or 10.8 t C, 1.38 t N, and 0.31 t TP. Biodeposits enriched by organic matter and nutrients provide a valuable food source for benthic deposit feeders, which often rely on sedimentary material for their diets (Lopez \& Levinton 1987). In Sishili Bay, the deposit feeder Stichopus japonicus (sea cucumber) is relatively abundant on the seabed under longlines, and the biodeposits produced by cultured scallops can serve as an important food source (Zhou et al. 2006b). In Sishili Bay, abundant commercial benthic animals, such as the Japanese stone crab Charybdis japonica (A. MilneEdwards) and the starfish Asterias amurensis Lütken (Zhou 2000) may also benefit from the enhanced benthic-pelagic coupling. Also, the enrichment of nitrogen and phosphorus in sediments may promote the growth of micro- and macrophytobenthos. In fact, macrophytobenthos, such as the brown algae Sargassum pallidum, appeared in large quantities $\left(\sim 2 \mathrm{~kg} \mathrm{~m}^{-2}\right)$ in shallower parts of the bay $(<5 \mathrm{~m})$ in summer. Therefore, the filtering-biodeposition by the suspension-cultured filter feeders not only delivered $\mathrm{N}$ and $\mathrm{P}$ nutrients from water column to bottom, but also reduced water column turbidity by removing both phytoplankton and inorganic particles from the water column, and thereby increased light penetration to the seabed for benthic plants that are light dependent.

Sediment traps are widely used in oceanic and coastal environments to measure the vertical flux of particulate material in the water column. Various kinds of poisons or preservatives are often used inside the traps to inhibit microbial decomposition. However, it has been observed that when these substances are used, contamination by planktonic swimmers (zooplankton which swim into the trap and die there from contact with the poisons) can be a serious problem as they may constitute a major part of the measured settling flux (Hedges et al. 1993). It is likely that, during short-time deployments, sediment trap measurements are more biased due to contamination by planktonic swimmers when preservatives are used than they are due to microbial decomposition when no preservatives are used (Hedges et al. 1993). In the present study, no preservatives were used; scallop biodeposits accumulated in the sediment traps for ca. $3 \mathrm{~d}$ before the traps were retrieved. Also in other studies (Kautsky \& Evans 1987, Jaramillo et al. 1992, Hatcher et al. 1994, Klerks et al. 1996, Peterson \& Heck Jr. 1999, Norkko et al. 2001), preservatives were not used when sediment traps for determination of biodeposition by wild bivalves in various aquatic systems were moored on the seabed/lakebed for several days, a week, 2 weeks or a month. Because no preservatives were used, the organic composition of the deposited material will have changed somewhat. This would make conclusions about the effects of the bivalves on the ecosystem conservative, i.e. it would somewhat underestimate the role of bivalves in biogeochemical processes. In order to estimate the microbial decomposition of organic matter in the biodeposits collected in traps, the experimental 1-yr-old scallops in each trap from 5 stations (S3, S5, D1, D2, D3) were placed in a container with $10 \mathrm{l}$ clean seawater, and fresh biodeposits produced by the scallops within $2 \mathrm{~h}$ were collected and analyzed. Results suggest that the reduction of biodeposit organic matter within 3 d was minor $(<10 \%)$, based on the difference in organic matter content between the trap biodeposits and the fresh biodeposits (OM $12.0 \pm 1.1 \%$ and $13.2 \pm 1.0 \%$, respectively).

Clearance rates (CR) of Chlamys farreri estimated by the biodeposition method in this study were in agreement with a recent report on this species (Hawkins et al. 2001). The filtration rates (FR) of 1-yr-old scallops exhibited a great variability among culture sites, ranging from 2.70 to $9.84 \mathrm{mg}$ ind. ${ }^{-1} \mathrm{~h}^{-1}$ with a strong positive correlation with seston concentrations (Fig. 6). Based on the mean CR of 1-yr-old scallops (1.72 1 ind. ${ }^{-1}$ $\mathrm{h}^{-1}$ ), the total Sishili Bay water column could theoretically be filtered by these scallops in ca. $12 \mathrm{~d}$ (assuming that this entire water column is within their reach). In previous studies in shallow bays with dense mussel populations, estimates of total filtering rate were extremely high. In Laholm Bay (Kattegat, Sweden), the dominant bivalves Cardium edule and Mya arenaria can filter the water column of 0 to $10 \mathrm{~m}$ (accounting for $20 \%$ of the bay) in $3 \mathrm{~d}$ (Loo \& Rosenberg 1989). The effects of scallop filtering-biodeposition on the water column in Sishili Bay can be extrapolated based on the 1-yr-old scallops' filtration rate measured in this work. The daily removal of suspended matter by scallops from a $1 \mathrm{~m}^{2}$ water column amounted to $17.3 \mathrm{~g}$, or a rate of $2.16 \mathrm{~g} \mathrm{~m}^{-3} \mathrm{~d}^{-1}$; thus, the scallops' daily removal of suspended matter from the water column in the bay was estimated to be as high as $64 \%$. Our recent study in field flow-through systems conducted in the bay (Zhou et al. 2006a) showed that the presence of Zhikong scallops can strongly decrease seston and chl a concentrations, and increase sedimentation rates. It has been suggested that the filtering-biodeposition process by bivalves can improve water quality by removing seston from the overlying water column, thus reducing the concentrations of suspended particles, detritus, and particulate-bound nutrients in aquatic systems (Haamer 1996). Reduction of seston concentrations in the water column by bivalves has been well documented (Riemann et al. 1988, Dame et al. 1991, 
Klerks et al. 1996, Cressman et al. 2003). The importance of this top-down pressure exerted by bivalves in coastal ecosystems is being increasingly recognized. For example, oyster reef habitat areas are now becoming an important conservation issue (Coen \& Luckenbach 2000). The role of oyster reef habitat in coastal ecosystems is likely mimicked by commercial bivalve operations. The present study indicates that the aquaculture of scallops in coastal waters with high nutrient loadings would be advantageous, serving as a eutrophication control, as seston level would be controlled and nutrients would be removed from the ecosystem whilst generating valuable products.

In Sishili Bay, substantial eutrophication has occurred as a result of increasing urban effluent and agricultural fertilizer runoff. It is estimated that yearly $\mathrm{N}$ and $\mathrm{P}$ inputs to the bay are 1910 and $150 \mathrm{t}$, respectively (Wu et al. 2001). A HAB event of Gymnodinium sangnineum occurred in the bay on a relatively large scale (ca. $100 \mathrm{~km}^{2}$ ) in early September 1998 (Zhou 2000, Wu et al. 2001). Because mass mortality of cultured scallops occurred widely in the bay in August before the occurrence of the red tide, it was suggested that at least part of the eutrophication might have resulted from losing the top-down control on phytoplankton biomass exerted by scallop filtering-biodeposition process. There is evidence that wild dense populations of filter-feeding bivalves can have a significant impact on basin-wide water quality and phytoplankton dynamics (Cloern 1982, Dame 1996); thus, disappearance of bivalve filter feeders may subsequently cause a substantial increase in phytoplankton biomass (Newell 2004). Some investigators, however, have suggested that bivalve populations may not be able to exert longlasting top-down control on phytoplankton populations, due to high levels of nutrient regeneration (direct excretion plus regeneration from biodeposits on the seabed). By contrast, in the Sishili Bay ecosystem, the following phenomenon could point to the occurrence of top-down control induced by the scallop filteringbiodeposition process. Although anthropogenic $\mathrm{N}$ and $\mathrm{P}$ inputs to the bay have increased due to activities such as industrial and urban effluent discharge and agricultural fertilizer run-off, chl a level and phytoplankton biomass in the bay have increased only slightly. During the experimental period, chl a averaged $2.71 \mu \mathrm{g} \mathrm{l}^{-1}$ in scallop culture sites (Table 1); basinwide average chl a was $2.22 \mathrm{\mu g} \mathrm{l}^{-1}$ and phytoplankton biomass was $1.73 \times 10^{6}$ cells m$^{-3}$ in summer 1997 , which were almost at the same levels as in 1982 and 1987, and much lower than in other eutrophic bays in Shandong Province, such as Jiaozhou Bay where chl a averaged $6 \mu \mathrm{g} \mathrm{l}^{-1}$ and phytoplankton biomass $5 \times$

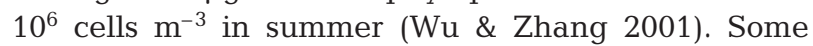
shellfish farmers even added $\mathrm{N}$ and $\mathrm{P}$ nutrients to the scallop culture sites artificially for several years to increase food concentration and thereby scallop growth; however, the result was not satisfactory, i.e. the phytoplankton biomass and scallop growth did not change markedly. We conclude that the suspensioncultured scallops in Sishili Bay ecosystem do induce a strong long-lasting top-down grazing control on phytoplankton biomass. The top-down control implies that bottom-up control on phytoplankton development (e.g. nutrient loading) is less important. Another phenomenon related to the loss of the top-down control by scallops was the occurrence of a jellyfish bloom (Eirene ceylonensis Browne; Zhou 2000) on a large scale in August 1998. The decline in scallop populations may have resulted in an increase in microplankton, followed by an increase in microzooplankton-feeding gelatinous macrozooplankton and a predominantly pelagic food web. A similar ecosystem change has been observed where decreases in oyster stocks in Chesapeake Bay during the past century were sufficient to cause a substantial increase in phytoplankton biomass (Newell 1988). Indeed, it has been estimated that the oysters living in Chesapeake Bay were once so abundant that they could filter the entire volume of the bay in just a few days, but they have declined so much that it would now require a year to filter the same volume of water (Newell 1988). The present study indicates that intensively suspension-cultured scallops could control phytoplankton biomass through grazing and control stocks of gelatinous zooplankton through competition.

Since the scallops in the present study significantly enhanced sedimentation, the intensive culture may have affected the benthic environment. The $\mathrm{NH}_{4}-\mathrm{N}$ concentration in porewater in sediment under scallop longlines was extremely high (Fig. 8), in agreement with previous studies (Kaspar et al. 1985, Grant et al. 1995) in which the sediment under suspended bivalve cultures had a large ammonium pool, from which ammonium release rates were high. The microbially mediated denitrification of organic nitrogen transferred to sediment surface in bivalve biodeposits may have a beneficial effect of permanently removing $\mathrm{N}$ in the form of $\mathrm{N}_{2}$ gas from the ecosystem (e.g. Kaspar et al. 1985, Prins et al. 1998, Newell 2004). Bivalve culture could thus function as a sink of nitrogen, removing nitrogen from the aquatic environment not only through the harvesting of the bivalves, but also due to the loss of nitrogen to the atmosphere. In the present study, sediment biogeochemical characteristics in scallop culture sites indicated that the adverse impact of suspended scallop culture on the benthic environment was not heavy, although scallop culture could somewhat increase contents of organic matter and acidvolatile sulfides (Fig. 7). This is in agreement with 
other studies (Grant et al. 1995, Chamberlain et al. 2001, Crawford et al. 2003). Although a shift toward anaerobic metabolism at bivalve culture sites may exist, the impact of the build-up of discarded cultured organisms, and fouling algae or ascidians beneath longline culture sites, is more noticeable than any impacts from bivalve biodeposition (Grant et al. 1995, Zhou 2000, Stenton-Dozey et al. 2001). In some cases, however, the accumulation of biodeposits in suspended cultures may result in a locally anoxic environment and faunal impoverishment (Haven \& MoralesAlamo 1966, Dahlbäck \& Gunnarsson 1981, StentonDozey et al. 2001, Waite et al. 2005). In Sishili Bay, surface sediments at 2 scallop culture sites were also anoxic in August, with AVS-S as high as $590 \mu \mathrm{g} \mathrm{g}^{-1}$ (Zhou 2000). Thus, bivalve stocking density should be constrained in the warm season to prevent local overenrichment of the sediments by biodeposits that can lead to anoxic conditions in the sediment.

In summary, suspended scallop aquaculture may have a significant impact on coastal ecosystems through the filtering-biodeposition process. Compared with wild bivalve filter feeders, whose distribution may be constrained by water depth and food supply, the bivalves intensively suspension-cultured in the water column in deeper coastal bays are potentially efficient processers of seston particles on a basin scale. Suspended scallop aquaculture in coastal waters with high nutrient loadings may be ecologically advantageous, functioning as biofilters or recyclers and mitigating eutrophication pressures on coastal ecosystems, through controling the seston level via the filteringbiodeposition process and removing nutrients from the ecosystem whilst generating valuable products. However, intensively cultured scallops may also deplete ambient water of particulate food, which may negatively influence the scallop growth.

Acknowledgements. We are deeply indebted to many individuals who contributed to the sampling program. We thank $\mathrm{Xu} \mathrm{XL}$ for his help in sample analysis. This project was financially supported by the National Natural Science Foundation of China (30100139/30571428), the Knowledge Innovation Key Projects of CAS (KZCX2-3SW-214/2SW-211), and the Special Funds for the Major State Basic Research Projects (G1999012012). We thank anonymous reviewers for helpful and constructive comments on the manuscript. The English was improved with the help of Dr. Roger Z. Yu.

\section{LITERATURE CITED}

Ahn IY (1993) Enhanced particle flux through the biodeposition by the Antarctic suspension-feeding bivalve Laternula elliptica in Marian Cove, King George Island. J Exp Mar Biol Ecol 171:75-90

Asmus RM, Asmus H (1991) Mussel beds: limiting or promoting phytoplankton? J Exp Mar Biol Ecol 148:215-232
Cerrato RM, Caron DA, Lonsdale DJ, Rose JM, Schaffner RA (2004) Effect of the northern quahog Mercenaria mercenaria on the development of blooms of the brown tide alga Aureococcus anophagefferens. Mar Ecol Prog Ser 281: 93-108

Chamberlain J, Fernandes TF, Read P, Nickell TD, Davies IM (2001) Impacts of biodeposits from suspended mussel (Mytilus edulis L.) culture on the surrounding surficial sediments. ICES J Mar Sci 58:411-416

Chiantore M, Cattaneo-Vietti R, Albertelli G, Misic C, Fabiano M (1998) Role of filtering and biodeposition by Adamussium colbecki in circulation of organic matter in Terra Nova Bay (Ross Sea, Antarctica). J Mar Syst 17: 411-424

Cloern JE (1982) Does the benthos control phytoplankton biomass in South San Francisco Bay? Mar Ecol Prog Ser 9: 191-202

Coen LD, Luckenbach MW (2000) Developing success criteria and goals for evaluating oyster reef restoration: ecological function or resource exploitation. Ecol Eng 15:323-343

Cranford PJ, Hargrave BT (1994) In situ time-series measurement of ingestion and absorption rates of suspension-feeding bivalves: Placopecten magellanicus. Limnol Oceanogr 39:730-738

Crawford CM, Macleod CKA, Mitchell IM (2003) Effects of shellfish farming on the benthic environment. Aquaculture 224:117-140

Cressman KA, Posey MH, Mallin MA, Leonard LA, Alphin TD (2003) Effects of oyster reefs on water quality in a tidal creek estuary. J Shellfish Res 22:753-762

Dahlbäck B, Gunnarsson LAH (1981) Sedimentation and sulfate reduction under a mussel culture. Mar Biol 63: 269-275

Dame RF (1996) Ecology of marine bivalves: an ecosystem approach. CRC Press, Boca Raton, FL

Dame RF, Prins TC (1998) Bivalve carrying capacity in coastal ecosystems. Aquat Ecol 31:409-421

Dame RF, Dankers N, Prins TC, Jongsma H, Smaal A (1991) The influence of mussel bed on nutrients in the western Wadden Sea and eastern Scheldt estuaries. Estuaries 142: $130-138$

FAO (2004) The state of world fisheries and aquaculture (SOFIA). FAO, Rome

Gifford S, Dunstan RH, O'Connor W, Roberts T, Toia R (2004) Pearl aquaculture-profitable environmental remediation? Sci Total Environ 319:27-37

Giles H, Pilditch CA (2004) Effects of diet on sinking rates and erosion thresholds of mussel Perna canaliculus biodeposits. Mar Ecol Prog Ser 282:205-219

Gottlieb SJ, Schweighofer ME (1996) Oysters and the Chesapeake Bay ecosystems: a case for exotic species introduction to improve environmental quality? Estuaries 19: 639-650

Grant J (1999) Ecological constraints on the sustainability of bivalve aquaculture. In: Svennevig N, Reinertsen $\mathrm{H}$, New $\mathrm{M}$ (eds) Sustainable aquaculture: food for the future? Proceedings of the Second International Symposium on Sustainable Aquaculture. Balkema, Rotterdam, p 85-96

Grant J, Bacher C (2001) A numerical model of flow modification induced by suspended aquaculture in a Chinese bay. Can J Fish Aquat Sci 58:1003-1011

Grant J, Hatcher A, Scott DB, Pocklington P, Schafer CT, Winters GV (1995) A multidisciplinary approach to evaluating impacts of shellfish aquaculture on benthic communities. Estuaries 18:124-144

Grasshoff K, Erhardt M, Kremling K (1983) Methods of seawater analysis. Verlag Chemie, Weinheim 
Grenz C, Hermin D, Baudinet D, Daumus R (1990) In situ biochemical and bacterial variation of sediments enriched with mussel biodeposits. Hydrobiologia 207:153-160

Guo XM, Ford SE, Zhang FS (1999) Molluscan aquaculture in China. J Shellfish Res 18:19- 31

Haamer J (1996) Improving water quality in a eutrophied fiord system with mussel farming. Ambio 25:356-362

Hatcher A, Grant J, Schofield B (1994) Effects of suspended mussel culture (Mytilus spp.) on sedimentation, benthic respiration and sediment nutrient dynamics in a coastal bay. Mar Ecol Prog Ser 115:219-235

Haven DS, Morales-Alamo R (1966) Aspects of biodeposition by oysters and other invertebrate filter feeders. Limnol Oceanogr 11:487-498

Hawkins AJS, Fang JG, Pascoe PL, Zhang JH, Zhang XL, Zhu MY (2001) Modelling short-term responsive adjustments in particle clearance rate among bivalve suspension-feeders: separate unimodal effects of seston volume and composition in the scallop Chlamys farreri. J Exp Mar Biol Ecol 262:61-73

Hedges JI, Lee C, Wakeham SG, Hernes PJ, Peterson ML (1993) Effects of poisons and preservatives on the fluxes and elemental compositions of sediment trap materials. J Mar Res 51:651-668

Iglesias JIP, Urrutia MB, Navarro E, Ibarrola I (1998) Measuring feeding and absorption in suspention-feeding bivalves: an appraisal of the biodeposition method. J Exp Mar Biol Ecol 219:71-86

Jaramillo E, Bertrán C, Bravo A (1992) Mussel biodeposition in an estuary in southern Chile. Mar Ecol Prog Ser 82: 85-94

Jordan JE,Valiela I (1982) A nitrogen budget of the ribbed mussel, Geukensia demissa, and its significance to nitrogen flow in a New England salt marsh. Limnol Oceanogr 27:75-90

Kaiser MJ, Laing I, Utting SD, Burnell GM (1998) Environmental impacts of bivalve mariculture. J Shellfish Res 17: $59-66$

Kaspar HF, Gillespie PA, Boyer IC, MacKenzie AL (1985) Effects of mussel aquaculture on the nitrogen cycle and benthic communities in Kenepuru Sound, Marlborough Sounds, New Zealand. Mar Biol 85:127-136

Kautsky N, Evans S (1987) Role of biodeposition by Mytilus edulis in the circulation of matter and nutrients in a Baltic coastal ecosystem. Mar Ecol Prog Ser 38:201-212

Klerks PL, Fraleigh PC, Lawniczak JE (1996) Effects of zebra mussels (Dreissena polymorpha) on seston levels and sediment deposition in western Lake Erie. Can J Fish Aquat Sci 53:2284-2291

Labarta U, Fernández-Reiríz MJ, Babarro JMF (1997) Differences in physiological energetics between intertidal and raft cultivated mussels Mytilus galloprovincialis. Mar Ecol Prog Ser 152:167-173

Loo LO, Rosenberg R (1989) Bivalve suspension-feeding dynamics and benthic-pelagic coupling in an eutrophicated marine bay. J Exp Mar Biol Ecol 130:253-276

Lopez GR, Levinton JS (1987) Ecology of deposit-feeding animals in marine sediments. Q Rev Biol 62:235-260

McCay DPF, Peterson CH, DeAlteris JT, Catena J (2003) Restoration that targets function as opposed to structure: replacing lost bivalve production and filtration. Mar Ecol Prog Ser 264:197-212

Navarro E, Iglesias JIP, Perez Camacho A, Labarta U and Beiras R (1991) The physiological energetics of mussels (Mytilus galloprovincialis Lmk) from different cultivation rafts in the Ria de Arosa (Galicia, N.W. Spain). Aquaculture 94:197-212
Newell RIE (1988) Ecological changes in Chesapeake Bay: Are they the result of overharvesting the Eastern oyster (Crassostrea virginica)? In: Lynch MP, Krome EC (eds) Understanding the estuary: advances in Chesapeake Bay research. Chesapeake Research Consortium Publication 129 (CBP/TRS 24/88), Gloucester Point, VA, p 536-546

Newell RIE (2004) Ecosystem influences of natural and cultivated populations of suspension-feeding bivalve molluscs: a review. J Shellfish Res 23:51-61

Norkko A, Hewitt JE, Thrush SF, Funnell GA (2001) Benthicpelagic coupling and suspension-feeding bivalves: linking site-specific sediment flux and biodeposition to benthic community structure. Limnol Oceanogr 46:2067-2072

Nunes JP, Ferreira JG, Gazeau F, Lencart-Silva J, Zhang XL, Zhu MY, Fang JG (2003) A model for sustainable management of shellfish polyculture in coastal bays, Aquaculture 219:257- 277

Officer CB, Smayda TJ, Mann R (1982) Benthic filter feeding: a natural eutrophication control. Mar Ecol Prog Ser 9: 203-210

Parsons TR, Maita Y, Lalli CM (1992) A manual of chemical and biological methods for seawater analysis. Pergamon Press. Oxford

Peterson BJ, Heck Jr KL (1999) The potential for suspension feeding bivalves to increase seagrass productivity. J Exp Mar Biol Ecol 240:37-52

Prins TC, Smaal AC, Dame RF (1998) A review of the feedbacks between bivalve grazing and ecosystem processes. Aquat Ecol 31:349-359

Riemann B, Nielsen TG, Horsted SJ, Koefoed Bjøernsen P, Pock-Steen J (1988) Regulation of phytoplankton biomass in estuarine enclosures. Mar Ecol Prog Ser 48:205-215

Smaal AC, Prins TC, Dankers N, Ball B (1998) Minimum requirements for modeling bivalve carrying capacity. Aquat Ecol 31:423-428

Solórzano L, Sharp JH (1980) Determination of total dissolved phosphorus and particulate phosphorus determination in natural waters. Limnol Oceanogr 25:754-758

Stenton-Dozey J, Probyn T, Busby A (2001) Impact of mussel (Mytilus galloprovincialis) raftculture on benthic macrofauna, in situ oxygen uptake, and nutrient fluxes in Saldanha Bay, South Africa. Can J Fish Aquat Sci 58: 1021-1031

Tenore KR, Dunstan WM (1973) Comparison of feeding and biodeposition of three bivalves at different food levels. Mar Biol 21:190-195

Tenore KR, Boyer LF, Cal RM, Corral J and 14 others (1982) Coastal upwelling in the Rias Bajas, NW Spain: contrasting the benthic regimes of the Rias de Arosa and de Muros. J Mar Res 40:701-772

Waite L, Grant J, Davidson J (2005). Bay-scale spatial growth variation of mussels Mytilus edulis in suspended culture, Prince Edward Island, Canada. Mar Ecol Prog Ser 297: 157-167

Widdows J, Brinsley MB, Salkeld PN, Elliott M (1998) Use of annular flumes to determine the influence of current velocity and biota on material flux at the sediment-water interface. Estuaries 21:552-559

Wong WH, Levinton JS, Twining BS, Fisher NS, Kelaher BP, Alt AK (2003) Assimilation of carbon from a rotifer by the mussels Mytilus edulis and Perna viridis: a potential foodweb link. Mar Ecol Prog Ser 253:175-182

Wu YL, Zhang YS (2001) Phytoplankton and primary production. In: Jiao NZ (ed) Ecological processes and sustainable development of typical coastal water ecosystems in China. Science Press, Beijing, p 96-108 (in Chinese, with English abstract) 
Wu YL, Zhou CX, Zhang YS, Pu XM, Li WH (2001) Evolution and causes of formation of Gymnodinium sangnineum bloom in Yantai Sishili Bay. Oceanol Limnol Sinica 32: 159-167 (in Chinese, with English abstract)

Yang HS, Zhang T, Wang J, Wang P, He YC, Zhang FS (1999) Growth characteristics of Chlamys farreri and its relation with environmental factors in intensive suspended-culture areas of Sishiliwan Bay, Yantai. J Shellfish Res 18:61-67

Zhang FS (2003). Aquaculture development in China: status and prospect. World Sci-Tech. R. \& D. 25(3):5-13

Zhang FS, Yang HS (1999) Analysis of the causes of mass mortality in Chlamys farreri in summer in coastal areas of Shandong, China. Mar Sci (China) 1:44-46 (in Chinese, with English abstract)

Zhou Y (2000) Foundational studies on effects of suspension culture of filter-feeding bivalves on coastal ecological environment. PhD dissertation. Chinese Academy of Sci-

Editorial responsibility: Kenneth Tenore (Contributing Editor), Solomons, Maryland, USA ences, Qingdao (in Chinese, with English abstract)

Zhou Y, Zhang FS, Yang HS, Zhang SM, Ma XN (2003) Comparison of effectiveness of different ashing auxiliaries for determination of phosphorus in natural waters, aquatic organism and sediments by ignition method. Water Res 37:3875-3882

Zhou Y, Yang HS, Zhang T, Qing PB, Xu XL, Zhang FS (2006a) Density-dependent effects on seston dynamics and rates of filtering and biodeposition of the suspensioncultured scallop Chlamys farreri in a eutrophic bay, northern China): an experimental study in semi-in situ flowthrough systems. J Mar Syst 59:143-158

Zhou Y, Yang HS, Liu SL, Yuan XT, Mao Y, Liu Y, Xu XL, Zhang FS (2006b) Feeding and growth on bivalve biodeposits by the deposit feeder Stichopus japonicus Selenka (Echinidermata: Holothuroidea) co-cultured in lantern nets. Aquaculture 256:510-520

Submitted: May 13, 2005; Accepted: November 22, 2005 Proofs received from author(s): June 20, 2006 